Loyalitas Kreativitas

Abdi Masyarakat Kreatif
P-ISSN 2722-2101, E-ISSN 2722-4201

Program Studi Ekonomi Manajemen Universitas Pamulang Jurnal LOKABMAS Kreatif Vol.02,No.02.Juli 2021Hal.89-97

Email:jurnalkreatif.manajemen@gmail.com

\title{
ADAPTASI KEHIDUPAN NEW NORMAL PADA MASA PANDEMI COVID-19 DIYAYASAN PONDOK PESANTREN DAN PANTI ASUHAN NURUL IKHSAN KECAMATAN SETU,KOTA TANGERANG SELATAN
}

\author{
Veta Lidya Delimah Pasaribu, ${ }^{1}$, Purba Satria ${ }^{2}$, Rani Permata Sari ${ }^{3}$ \\ ,Irene Valencya ${ }^{4}$, Resti Setyowati ${ }^{5}$, Nursahidin ${ }^{6}$ \\ ${ }^{1}$ Dosen Universitas Pamulang \\ $.2,3,4,5,6$ Mahasiswa Fakultas Ekonomi Jurusan Manajemen S1
}

Email : Dosen01889@unpam.ac.id,pbossatria17@gmail.com, valencya2899@gmail.com , nursahidin23@gmail.com, rani80permatasari@gmail.com, restisetyowati99@gmail.com

\begin{abstract}
ABSTRAK
Tujuan dari Pengabdian kepada Masyarakat (PKM) ini adalah untuk mengetahui dan mensosialisasikan tata cara adaptasi pada pola kondisi New Normal di masa Pandemi Covid19 di Yayasan Nurul Ihsan Kecamatan Setu Kota Tangerang Selatan Provinsi Banten. Metode yang digunakan dalam PKM ini adalah penyuluhan kepada warga Masyarakat yang berada di Yayasan Nurul Ihsan di Setu Kota Tangerang Selatan, tentang : Pemahaman masyarakat terhadap pola hidup New Normal di Masa Pandemi Covid-19. Serta pemahaman masyarakat terhadap pentingnya pola hidup yang sehat di masa pandemi.

Hasil dari pelaksanaan PKM ini, diharapkan warga masyarakat Yayasan Nurul Ihsan Kecamatan Kademangan Kota Tangerang Selatan dapat memahami secara optimal pola hidup dan cara beradaptasi di masa Pandemi Covid-19 saat ini.
\end{abstract}

\section{Kata kunci : Adaptasi, New Normal,Covid-19}

\begin{abstract}
ABSRACT
The purpose of Community Service (PKM) is to find out and disseminate adaption procedures during a pandemic Covid-19 Nurul Ihsan Foundation, Setu District South of Tangerang, Banten.

The method used in this PKM is counseling to the Nurul Ihsan foundation of Setu South Tangerang Banten, about: community understanding of the New Normal lifestyle during the Covid-19 Pandemic. As well as community understanding of the importance of a healthy lifestyle during a pandemic.

The results of the implementation of this PKM, it is hoped that the people of Nurul Ihsan foundation, Setu Districy, South of Tangerang, Banten, can optimally understand can optimally understand the lifestyle and how to adapt during the current Covid-19 Pandemic.
\end{abstract}

Key words: Adaptation. New Normal,Covid-19 


\section{Loyalitas Kreativitas Aldi Masyarakat Kreatif}

P-ISSN 2722-2101, E-ISSN 2722-4201

Program Studi Ekonomi Manajemen Universitas Pamulang

Jurnal LOKABMAS Kreatif Vol.02,No.02.Juli 2021Hal.89-97

Email:jurnalkreatif.manajemen@gmail.com

\section{PENDAHULUAN}

Coronavirus merupakan keluarga besar virus yang menyebabkan penyakit pada manusia dan hewan. Pada manusia biasanya menyebabkan penyakit infeksi saluran pernapasan, mulai flu biasa hingga penyakit yang serius seperti Middle East Respiratory Syndrome (MERS) dan Sindrom Pernafasan Akut Berat/ Severe Acute Respiratory Syndrome (SARS). Coronavirus jenis baru yang ditemukan pada manusia sejak kejadian luar biasa muncul di Wuhan Cina, pada Desember 2019, kemudian diberi nama Severe Acute Respiratory Syndrome Coronavirus 2 (SARS-COV2), dan menyebabkan penyakit Coronavirus Disease-2019 (COVID-19).

Seperti penyakit pernapasan lainnya, COVID-19 dapat menyebabkan gejala ringan termasuk pilek, sakit tenggorokan, batuk, dan demam. Sekitar 80\% kasus dapat pulih tanpa perlu perawatan khusus. Sekitar 1 dari setiap 6 orang mungkin akan menderita sakit yang parah, seperti disertai pneumonia atau kesulitan bernafas, yang biasanya muncul secara bertahap. Walaupun angka kematian penyakit ini masih rendah (sekitar 3\%), namun bagi orang yang berusia lanjut, dan orangorang dengan kondisi medis yang sudah ada sebelumnya (seperti diabetes, tekanan darah tinggi dan penyakit jantung), mereka biasanya lebih rentan untuk menjadi sakit parah. Melihat perkembangan hingga saat ini, lebih dari 50\% kasus konfirmasi telah dinyatakan membaik, dan angka kesembuhan akan terus meningkat.

Seseorang dapat terinfeksi dari penderita COVID-19. Penyakit ini dapat menyebar melalui tetesan kecil (droplet) dari hidung atau mulut pada saat batuk atau bersin. Droplet tersebut kemudian jatuh pada benda di sekitarnya. Kemudian jika ada orang lain menyentuh benda yang sudah terkontaminasi dengan droplet tersebut, lalu orang itu menyentuh mata, hidung atau mulut (segitiga wajah), maka orang itu dapat terinfeksi COVID-19. Atau bisa juga seseorang terinfeksi COVID19 ketika tanpa sengaja menghirup droplet dari penderita. Inilah sebabnya mengapa kita penting untuk menjaga jarak hingga kurang lebih satu meter dari orang yang sakit.Sampai saat ini, para ahli masih terus melakukan penyelidikan untuk menentukan sumber virus, jenis paparan, dan cara penularannya. Tetap pantau sumber informasi yang akurat dan resmi mengenai perkembangan penyakit ini.

Beberapa hal yang perlu diperhatikan agar bisa terhindar dari Corona Virus, antara lain menjaga kesehatan dan kebugaran agar stamina tubuh tetap prima dan sistem imunitas / kekebalan tubuh meningkat. Mencuci tangan dengan benar secara teratur menggunakan air dan sabun atau hand-rub berbasis alkohol. Mencuci tangan sampai bersih selain dapat membunuh virus yang mungkin ada di tangan kita, tindakan ini juga merupakan salah satu tindakan yang mudah dan murah. Sekitar 98\% penyebaran penyakit 


\section{Loyalitas Kreativitas Aldi Masyarakat Kreatif}

P-ISSN 2722-2101, E-ISSN 2722-4201

Program Studi Ekonomi Manajemen Universitas Pamulang

Jurnal LOKABMAS Kreatif Vol.02,No.02.Juli 2021Hal.89-97

Email:jurnalkreatif.manajemen@gmail.com bersumber dari tangan. Karena itu, menjaga kebersihan tangan adalah hal yang sangat penting. Ketika batuk dan bersin, tutup hidung dan mulut Anda dengan tisu atau lengan atas bagian dalam (bukan dengan telapak tangan).

Hindari kontak dengan orang lain atau bepergian ke tempat umum. Hindari menyentuh mata, hidung dan mulut (segitiga wajah). Tangan menyentuh banyak hal yang dapat terkontaminasi virus. Jika kita menyentuh mata, hidung dan mulut dengan tangan yang terkontaminasi, maka virus dapat dengan mudah masuk ke tubuh kita. Gunakan masker dengan benar hingga menutupi mulut dan hidung ketika Anda sakit atau saat berada di tempat umum. Buang tisu dan masker yang sudah digunakan ke tempat sampah dengan benar, lalu cucilah tangan Anda. Menunda perjalanan ke daerah/ negara dimana virus ini ditemukan. Hindari bepergian ke luar rumah saat Anda merasa kurang sehat, terutama jika Anda merasa demam, batuk, dan sulit bernapas. Segera hubungi petugas kesehatan terdekat, dan mintalah bantuan mereka. Sampaikan pada petugas jika dalam 14 hari sebelumnya Anda pernah melakukan perjalanan terutama ke negara terjangkit, atau pernah kontak erat dengan orang yang memiliki gejala yang sama. Ikuti arahan dari petugas kesehatan setempat.

Selalu pantau perkembangan penyakit COVID-19 dari sumber resmi dan akurat. Ikuti arahan dan informasi dari petugas kesehatan dan Dinas Kesehatan setempat. Informasi dari sumber yang tepat dapat membantu Anda melindungi dari Anda dari penularan dan penyebaran penyakit ini.

Apa yang disebut sebagai New Normal ? Ketua Tim Pakar Gugus Tugas Percepatan Penanganan Covid-19 Wiku Adisasmita mengatakan, new normal adalah perubahan perilaku untuk tetap menjalankan aktivitas normal namun dengan ditambah menerapkan protokol kesehatan guna mencegah terjadinya penularan Covid-19. Menurut Wiku, prinsip utama dari new normal itu sendiri adalah dapat menyesuaikan dengan pola hidup. "Secara sosial, kita pasti akan mengalami sesuatu bentuk new normal atau kita harus beradaptasi dengan beraktivitas, dan bekerja, dan tentunya harus mengurangi kontak fisik dengan orang lain, dan menghindari kerumunan, serta bekerja, bersekolah dari rumah," Dijelaskan juga secara sosial disadari bahwa hal ini akan berpengaruh. Pasalnya, ada aturan yang disebutkan dalam protokol kesehatan untuk menjaga jarak sosial dengan mengurangi kontak fisik dengan orang lain. Masyarakat, kata Wiku, akan menjalani kehidupan secara new normal hingga ditemukannya vaksin dan dapat digunakan sebagai penangkal virus corona. "Transformasi ini adalah untuk menata kehidupan dan perilaku baru, ketika pandemi, yang kemudian akan dibawa terus ke depannya sampai tertemukannya vaksin untuk Covid-19," katanya lagi. Beberapa ahli dan pakar kesehatan dunia telah memastikan bahwa kemungkinan paling cepat 


\section{Loyalitas Kreativitas Aldi Masyarakat Kreatif}

P-ISSN 2722-2101, E-ISSN 2722-4201

Program Studi Ekonomi Manajemen Universitas Pamulang

Jurnal LOKABMAS Kreatif Vol.02,No.02.Juli 2021Hal.89-97

Email:jurnalkreatif.manajemen@gmail.com dapat ditemukannya vaksin adalah pada 2021.

Artinya, masyarakat harus menjalani kehidupan secara new normal hingga tahun depan, bahkan lebih. Oleh karenanya, perubahan perilaku akan menjadi kunci optimisme dalam menghadapi Covid-19 dengan menerapkan protokol kesehatan sesuai anjuran pemerintah atau yang dikenal sebagai new normal. "Tapi kita harus berpikiran positif, karena Indonesia punya kapasitas yang besar dan gotong royong, marilah kita gotong royong agar terbebas dari Covid-19," imbuhnya. Dikutip dari pemberitaan Kompas.com, Selasa (19/5/2020), konsep pola hidup normal baru ini merupakan salah satu yang ditekankan oleh Badan Kesehatan Dunia (WHO). Direktur Jenderal WHO Tedros Adhanom Ghebreyesus menyebutkan sejumlah hal yang harus diperhatikan pemerintah suatu wilayah atau negara untuk melonggarkan pembatasan terkait pandemi Covid-19

Dengan diadakannya kegiatan PKM di Yayasan Nurul Ihsan Kecamatan Setu Kota Tangerang Selatan Banten, kami dapat memberikan pengetahuan dan wawasan lebih kepada warga masyarakat tentang pengertian dan tata cara adaptasi hidup New Normal di masa Pandemi Covid-19 ini. Melakukan aktifitas normal seperti biasa namun tetap menerapkan protokol kesehatan, seperti halnya menggunakan masker saat beraktifitas, selalu menjaga kebersihan dengan mencuci tangan, serta menghindari kerumunan, dan yang terakhir tetap jaga kesehatan dengan mengkonsumsi vitamin agar daya tahan tubuh tetap fit.

Rumusan masalah kegiatan PKM ini adalah sebagai berikut :

1. Bagaimana warga masyarakat di Yayasan Pondok Pesantren Dan Panti Asuhan Nurul Ihsan bisa memahami pola hidup New Normal di masa pandemi ?

2. Bagaimana warga masyarakat di Yayasan Pondok Pesantren dan Panti Asuhan Nurul Ihsan bisa beradaptasi dan memulai aktifitas seperti biasa dengan tetap menerapkan protokol kesehatan di masa pandemi covid-19 di wilayah sekitar?

Tujuan kegiatan PKM di Yayasan Pondok Pesantren dan Panti Asuhan Nurul Ihsan sebagai berikut:

1. Untuk mengetahui warga masyarakat Yayasan Pondok Pesantren dan Panti Asuhan Nurul Ihsan terhadap pola hidup New Normal.

2. Untuk mengetahui secara optimal bagaimana warga masyarakat Yayasan Pondok Pesantren dan Panti Asuhan Nurul Ihsan memahami cara beradaptasi serta tetap mengutamakan protokol kesehatan pada New Normal di masa Pandemi .

\section{METODE PELAKSANAAN}




\section{Loyalitas Kreativitas Aldi Masyarakat Kreatif}

P-ISSN 2722-2101, E-ISSN 2722-4201

Program Studi Ekonomi Manajemen Universitas Pamulang

Jurnal LOKABMAS Kreatif Vol.02,No.02.Juli 2021Hal.89-97

Email:jurnalkreatif.manajemen@gmail.com
Tahapan yang dilakukan dalam kegiatan ini adalah survei awal dimana kami melakukan kunjungan ke Yayasan Pondok Pesantren dan Panti Asuhan Nurul Ihsan untuk membicarakan teknik pelaksanaan dan tanggal pelaksanaan serta memberitahu apa yang akan kami lakukan dan penyusunanbahan/materi kegiatan yang meliputi: slide powerpoint dan handout. Metode kegiatan yang digunakan kepada peserta adalah dengan memberikan penjelasan materi terlebih dahulu. Pelaksanaan dilakukan pada tanggal 21 Maret 2021. Peserta pada kegiatan ini adalah masyarakat yang ada di Yayasan Pondok Pesantren dan Panti Asuhan Nurul Ihsan.

Tahapan Selanjutnya melaksanakan kegiatan ini digunakan 3 metode, yaitu: Metode Penjelasan Teori Sederhana Memberikan penjelasan singkat dan sederhana konsep, Metode Peragaan Melakukan peragaan insitusi. Melakukan diskusi dengan para peserta Yayasan Pondok Pesantren dan Panti Asuhan Nurul Ihsan. untuk membuka wawasan tentang pentingnya menerapkan protokol kesehatan sesuai anjuran pemerintah atau yang dikenal sebagai new normal.

\section{Realisasi Pemecahan Masalah}

Berdasarkan solusi yang diusulkan maka target yang diharapkan sebagai berikut:

1. Masyarakat di Yayasan Pondok Pesantren dan Panti Asuhan Nurul Ihsan memahami tentang pola hidup New Normal di masa pandemi.

2. Masyarakat di Yayasan Pondok Pesantren dan Panti Asuhan Nurul Ihsan bisa beradaptasi dan memulai aktifitas seperti biasa dengan tetap menerapkan protokol kesehatan di masa pandemi covid-19 di wilayah sekitar.

\section{Khalayak Sasaran}

Peserta kegiatan : Yayasan Pondok Pesantren dan Panti Asuhan Nurul Ihsan

\section{Tempat dan Waktu}

Tempat Kegiatan Yayasan Pondok Pesantren dan Panti Asuhan Nurul Ihsan

Waktu Pelaksanaan : Minggu, 21 Maret 2021

Jam 09.00 - 15.00 WIB

\section{TUJUAN KEGIATAN}

Memberikan pemahaman kepada masyarakat Yayasan Pondok Pesantren dan Panti Asuhan Nurul Ihsan bahwa dengan adanya new normal dapat meningkatkan produktivitas masyarakat di tingkat ekonomi seperti sektor UMKM dapat kembali pulih dan tetap juga untuk melaksanakan protokol 


\section{Loyalitas Kreativitas Aldi Masyarakat Kreatif}

P-ISSN 2722-2101, E-ISSN 2722-4201

Program Studi Ekonomi Manajemen Universitas Pamulang

Jurnal LOKABMAS Kreatif Vol.02,No.02.Juli 2021Hal.89-97

Email:jurnalkreatif.manajemen@gmail.com kesehatan yang dibuat oleh pemerintah, dapat meningkatkan kinerja masyarakat yang telah lama berada di rumah karena di PHK. Dan dengan adanya pemberlakuan "new normal" ini juga masyarakatmasyarakat dapat kembali beraktivitas dan bekerja seperti biasa nya dan tetap menjaga kesehatan dengan memberlakukan protokol kesehatan pada diri masing-masing dengan memakai masker, rajin mencuci tangan, dan tetap menjaga jarak terhadap orang sekitar .

\section{HASIL DAN PEMBAHASAN}

New normal adalah perubahan perilaku atau kebiasaan untuk tetap menjalankan aktivitas seperti biasa namun dengan selalu menerapkan protokol kesehatan di tengah pandemi COVID-19. Himbauan dari pemerintah ini menganjurkan agar kita bisa hidup "berdampingan" dengan virus yang telah menelan ratusan ribu jiwa di seluruh dunia.

Sejak pandemi COVID-19 muncul, hampir semua orang mengalami kendala untuk menjalani kehidupan normal akibat pembatasan yang perlu dilakukan untuk mencegah penularan virus Corona.

Namun, dengan usainya pembatasan tersebut, pemerintah menganjurkan kita untuk mulai melakukan kegiatan seperti biasa, tentunya sambil mematuhi protokol pencegahan COVID-19.
Hal ini mendorong kita untuk lebih gencar dalam menerapkan langkah pencegahan dasar COVID-19, seperti mencuci tangan dengan sabun dan air mengalir atau dengan hand sanitizer, tidak menyentuh wajah dengan tangan yang belum dicuci, menerapkan physical distancing, serta mengenakan masker dalam setiap aktivitas, terutama di tempat umum.

\section{Cara Beraktivitas selama New Normal}

Berikut adalah hal-hal penting yang perlu kamu ketahui untuk menghadapi new normal:

- Buka alas kaki sebelum masuk ke dalam rumah.

- Semprotkan disinfektan pada alas kaki maupun peralatan yang kamu gunakan.

- Cuci tangan dengan air dan sabun.

- Lepaskan pakaian yang dikenakan dan segera masukkan ke dalam tempat cucian yang tertutup.

- Mandi dan berganti pakaian bersih sebelum bersantai atau berkumpul dengan keluarga.

Bila kamu harus bepergian ke suatu tempat dan menggunakan transportasi umum, ada beberapa hal yang perlu diperhatikan selain menerapkan langkah pencegahan dasar.

Untuk memudahkanmu dalam menjaga kebersihan tangan, bawalah selalu hand sanitizer. Jangan menyentuh wajah dengan tangan yang belum dibersihkan. 
Selain itu, pastikan kamu membawa botol minum agar tetap terhidrasi selama perjalanan.

Yang paling penting untuk diingat selama berada di dalam transportasi umum adalah mengurangi interaksi dan menjaga jarak setidaknya 1 meter dengan penumpang lain. Bila hal ini tidak memungkinkan, sebaiknya jangan menggunakan transportasi umum.

Selain itu, usahakan untuk tidak berlama-lama saat belanja. Catat barang-barang apa saja yang perlu dibeli dan langsung ke kasir ketika semua sudah Anda dapatkan.

Sewaktu membayar, gunakan metode pembayaran nontunai untuk mencegah kontaminasi. Namun, jika tidak memungkinkan, pastikan untuk langsung mencuci tangan setelah memegang uang ataupun kartu.

Alih-alih berkonsultasi langsung dengan dokter di rumah sakit, lebih baik gunakan fasilitas telemedicine. Kita bisa untuk berkonsultasi dengan dokter umum maupun dokter spesialis.

Kendati kehidupan dengan new normal telah dicanangkan oleh pemerintah, bukan berarti virus Corona telah hilang dan tidak lagi menjadi ancaman. Oleh karena itu, kita tetap harus memperkuat daya tahan tubuh dengan memerhatikan asupan nutrisi dan cairan, serta menerapkan pola hidup sehat, seperti beristirahat yang cukup, rutin berolahraga, mengelola stres dengan baik, serta tidak merokok.

Penting untuk diingat, jangan memaksakan diri untuk keluar rumah bila sedang tidak sehat, apalagi jika kamu mengalami gejala COVID-19, seperti demam, batuk, sesak napas, pilek, atau sakit tenggorokan. Segera lakukan isolasi mandiri. Dengan begitu, kamu juga akan melindungi orang lain dari risiko terpapar virus Corona.

Selain itu, hubungi juga hotline COVID-19 di 119 Ext. 9 untuk mendapatkan pengarahan lebih lanjut. Bila memang memenuhi kriteria, dinas kesehatan bisa menjemput dan mengantarkanmu langsung ke fasilitas layanan kesehatan atau rumah sakit rujukan COVID-19 terdekat untuk mendapatkan pengobatan.

\section{KESIMPULAN DAN SARAN}

\section{Kesimpulan}

Aktivitas yang dilakukan di masa new normal tentu belum sepenuhnya aman. Pasalnya kita harus hidup berdampingan dengan Covid-19, sadar akan kehadirannya yang sewaktu-waktu berpotensi menginfeksi kita. Maka proteksi wajib kita lakukan untuk melindungi diri kita dan orang lain. Memakai masker, menjaga jarak sosial maupun fisik, rajin mencuci tangan, serta disiplin mengikuti protokol kesehatan wajib kita patuhi.

Kepatuhan ini bukan semata-mata karena perintah atau kebijakan pemerintah, namun harus sudah melekat sebagai sebuah kebutuhan yang disadari oleh masyarakat. Kesadaran diri dan pengetahuan masyarakat mengenai new normal 


\section{Loyalitas Kreativitas Aldi Masyarakat Kreatif}

P-ISSN 2722-2101, E-ISSN 2722-4201

Program Studi Ekonomi Manajemen Universitas Pamulang

Jurnal LOKABMAS Kreatif Vol.02,No.02.Juli 2021Hal.89-97

Email:jurnalkreatif.manajemen@gmail.com akan membuat masyarakat paham sehingga melahirkan kepedulian terhadap diri sendiri serta orang lain.

Sebagai masyarakat kita adalah garda terdepan dalam menghadapi Covid-19, sedangkan dokter dan ahli kesehatan lainnya merupakan garda terakhir. Semakin masyarakat peduli dan sadar akan bahaya Covid-19, maka penanganan menjadi lebih mudah. Dokter dan ahli kesehatan akan fokus terhadap penanganan kasus orang yang sudah terpapar virus. Sedangkan masyarakat berupaya meminimalisir terjadinya penularan.

\section{Saran}

1. Perlu adanya sosialisasi ke masyakarat secara terus menerus tentang pentingnya mengikuti protokol kesehatan yang berlaku.

2. Perlu dukungan baik dari pemerintah dan masyarakat bersama-sama mengajak semua untuk membangun kesadaran dan kepedulian dalam menjalankan protokol kesehatan.

\section{DAFTAR PUSTAKA}

Arikunto, Suharsimi. 2008. DasarDasar Evaluasi Pembelajaran. Jakarta: Bumi Aksara. 308 hlmn.

Hulasoh, E., Syamsuddin, R. A., Praditya, A., Lisdawati, \& Supardi. (2020). Pengaruh Gadget Terhadap Prestasi Belajar Remaja Di Era Milenial Pada Lembaga Bimbingan Belajar Daarul 'Uluum
Petukangan Utara, Pesanggrahan, Jakarta Selatan. ABDIMAS

Krisnaldy, 2019, Pengembangan Minat Wirausaha UMKM , Jakarta Selatan

Kartini Kartono, 2008, Pemimpin dan kepemimpinan. Jakarta: Raja Grafindo Persada

Pasaribu, V. L. D., Agrasadya, A., Shabrina, N., \& Krisnaldy, K. (2020). Menjadi Enterpreneur Muda Yang Memiliki Jiwa Leadership Untuk Menghadapi Masa Depan. Abdi Laksana: Jurnal Pengabdian Kepada Masyarakat, 1(1).

Pasaribu, V. L. D., Susanti, F., \& Hartuti, E. T. K. (2019). Memotivasi Siswa dan Siswi SMK Letris Indonesia di Dalam Menentukan Pilihan Untuk Melanjutkan Pendidikan Atau Bekerja Setelah Lulus Sekolah. Jurnal

Pengabdian Dharma

Laksana, 1(2), 161-172.

Pasaribu, V. L. D., Sulaiman, S., Sutiman, S., Thaharudin, T., \& Purnomo, B. Y. (2020). Pengenalan Letak Posyandu Terdekat Dikelurahan Pisangan Dengan Manajemen Pemasaran Revolusi 4.0 Untuk Meningkatkan Pengetahuan Masyarakat Letak Dan Fungsi Posyandu Terdekat Pada Kelurahan Pisangan. Dedikasi Pkm, 1(1), 105-110.

Pasaribu, V. L. D., Oktrima, B., Prabowo, B., Arianto, N., \& Haryoko, U. B. (2020). Progam Pendampingan Dan Penyelenggaraan Pendidikan 


\section{Loyalitas Kreativitas Aledi Masyarakat Kreatif}

P-ISSN 2722-2101, E-ISSN 2722-4201

Program Studi Ekonomi Manajemen Universitas Pamulang

Jurnal LOKABMAS Kreatif Vol.02,No.02.Juli 2021Hal.89-97

Email:jurnalkreatif.manajemen@gmail.com
Anak Pada Usia Dini Terhadap Prestasi Belajar Dilingkungan Rt 020 Rw 009. Kel Giri Peni. Kec Wates. Yogyakarta. Jurnal Lokabmas Kreatif, 1(1), 71-75.

Pasaribu, V. L. D., Jannah, M., Fazar, M., Putra, S. P., Monalisa, M., \& Sofa, M. (2021). MENINGKATKAN PRODUKTIVITAS USAHA DIMASA PANDEMI PADA IBU PKK RT 004/003 KELURAHAN SAWAH BARU CIPUTAT, TANGERANG SELATAN. Abdi Laksana: Jurnal Pengabdian Kepada Masyarakat, 2(2), 295301.

Pasaribu, V. L. D., Yuniati, H. L., Pranata, R., Sembayu, R., Purba, S. M., \& Nurbayani, T. T. A. (2021). MANAJEMEN KEUANGAN UNTUK MENGHADAPI DAN BERTAHAN DI ERA COVID 19. Jurnal Abdimas Tri Dharma Manajemen, 2(2), 12-18.

Pasaribu, V. L. D., Dwiyatni, A., Sabina, C., Ridwan, M., Gunawan, D. D., \& Noviani, B. C. (2021). EVALUASI PENERAPAN 3M DIMASA PANDEMIC COVID 19. Jurnal Abdimas Tri Dharma Manajemen, 2(2), 54-60.

Pasaribu, V. L. D., Syafei, A. N., Farhan, A., Aufaizah, A., Irani, C., \& Firtiayani, S. R. (2021). PENGARUH DISPLIN PROTOKOL KESEHATAN TERHADAP PENCEGAHAN PENULARAN VIRUS COVID19. Jurnal Abdimas Tri Dharma Manajemen, 2(2), 91-98.

\section{KARYAWAN PT BNI KCP PAMULANG. ProBank. https://doi.org/10.36587/probank.v5i 2.723}

Rahmi Andini Syamsuddin, Lisdawati, \& Agung Tri Putranto. (2020). Evaluation Performance of Social Organization in Setu District - South Tangerang. Jurnal Ekonomi \& Bisnis JAGADITHA. https://doi.org/10.22225/ji.7. 2.2483.123-127

https://www.kemkes.go.id/folder/v iew/fullcontent/structure-faq.html

https://www.kemkes.go.id/article/v iew/20052900001/vksin-covid-19belum-ditemukan-pemerintahsiapkanskenario-new-normal.html

https://www.kompas.com/tren/read /2020/05/20/063100865/mengenalapa-itu-new-normal-di-tengahpandemi-corona-?page $=$ all

https://www.alodokter.com/inipanduan-menjalani-new-normalsaat-pandemi-corona

https://news.detik.com/kolom/d5097523/new-normal-sebagaigaya-hidup

Pratama, A., \& Syamsuddin, R. A. (2020).

DAMPAK KOMITMEN ORGANISASI ATAS KINERJA 